\title{
Immunogold labelling of beet necrotic yellow vein virus particles inside its fungal vector, Polymyxa betae K
}

\author{
P Rysanek *, G Stocky, AM Haeberlé, C Putz ** \\ INRA, Station Grandes Cultures, Laboratoire de Pathologie Végétale, 68021 Colmar Cedex, France
}

(Received 3 february 1992; accepted 4 June 1992)

\begin{abstract}
Summary - Many aspects of the association of Polymyxa betae with beet necrotic yellow vein virus during transmission have not been elucidated. In order to study the specificity of virus acquisition by the vector and its transmission to the host, thin sections were made through sugar beet roots infected both by the virus and the fungus. Immunogold labelled virus was identified at different stages of the fungus (plasmodia, zoosporangia and mature zoospores). However, specifically labelled clusters of virions have not yet been observed in mature resting spores.
\end{abstract}

beet necrotic yellow vein virus / Polymyxa betae / immunogold labelling / virus-vector association

\begin{abstract}
Résumé - Marquage à l'or collö̈dal du virus des nervures jaunes et nécrotiques de la betterave dans le champignon vecteur Polymyxa betae K. De nombreuses questions relatives à l'association entre Polymyxa betae et le virus de la rhizomanie qu'il transmet restent sans réponse. Dans le but de mieux appréhender la spécificité de l'acquisition du virus par son vecteur ainsi que sa transmission à la plante hôte, des coupes ultrafines ont été réalisées dans des radicelles de betterave sucrière infectées à la fois par le virus et le champignon, puis soumises au marquage immunocytochimique. Du virus marqué à l'or collö̈dal a été détecté dans différents stades du champignon (plasmodes, zoosporanges, zoospores bien différenciées). Cependant, des amas caractéristiques de BNYVV n'ont pu être mis en évidence dans les cystosores et les spores de repos, probablement en raison de la difficulté de pénétration des résines dans de tels tissus.
\end{abstract}

marquage immunocytologique à l'or / BNYVV / virus / Polymyxa betae / association virus-champignon vecteur

\section{INTRODUCTION}

Beet necrotic yellow vein virus (BNYVV) is a rod-shaped virus of sugar beets (Tamada and Baba, 1973), described in Japan, Europe, North America, China and the former Soviet Union. It is the causative agent of an important disease called rhizomania. BNYVV is transmitted by the soil-borne plasmodiophoraceous fungus Polymyxa betae K (Keskin, 1964) an obligate parasite of plants from the families Chenopodiaceae, Portulaceae and Amaranthaceae (Canova, 1966; Tamada, 1975; Fujisawa and Sugimoto, 1977).

More than 20 different viruses are now believed to be transmitted by lower fungi from the orders Plasmodiophoromycetes and Chytridiomycetes (Brunt and Richards, 1989; Adams,
1991). However, the details of the mechanism of transmission and association between fungallytransmitted viruses and their vectors are still unknown.

Earlier attempts to find the virus in the zoospores of Polymyxa failed. Giunchedi and Langenberg (1982) examined more that 220 zoospores without success. Furthermore, earlier work provided no definite proof of the presence of particles in the fungus. Tamada (1975) presented a micrograph of "virus-like particles" of BNYVV in a zoospore, but the image did not allow the fine structure of the putative virus particles to be distinguished. Other papers dealing with the subject did not present micrographs (Tamada et al, 1975; Stocky et al, 1977; Vuittenez and Stocky, 1979). Fujisawa and Sugimoto (1977) reported finding rod-shaped particles in resting-

\footnotetext{
* Present address: University of Agriculture, Department of Plant Pathology, 16521 Praha-Suchdol, Czechoslovakia

** Correspondence and reprints
} 
spores of $P$ betae but the number of particles detected was too small to allow definite conclusions to be drawn.

Owing to the density of the fungal cytoplasmic contents, viral particles are difficult to see within fungal plasmodia, zoosporangia or cystosori. The association of Polymyxa betae with the virus it transmits is thought to be internal; according to Tamada (1975), zoospores with virus have been found and cystosori in dry BNYVV-infected roots remain able to transmit BNYVV to beet seedlings for a long period of time. Langenberg and Giunchedi (1982), found virus particles in close contact with the fungal vector in the host tissue, but they were always outside the fungal structures. Allaham and Stocky (1983), Vuittenez et al (1984), and afterwards Abe and Tamada (1986), published convincing electron micrographs of virus-like particles in immature zoospores of Polymyxa betae. Recently, Jianping et al (1991), using immunogold labelling, have described the presence of a bymovirus, barley mild mosaic virus, inside Polymyxa graminis.

Here we show the presence of immunogoldlabelled BNYVV particles in young plasmodia, zoosporangial and cystogenous plasmodia, in a mature zoospore in a zoosporangium and in a free zoospore of Polymyxa betae outside the root cells. This paper thus demonstrates the association of $P$ betae with BNYVV using immunogold labelling techniques.

\section{MATERIALS AND METHODS}

\section{Virus, fungus and host plants}

Soil from a contaminated field near Strasbourg was used as source of viruliferous Polymyxa betae. The soil had been shown to be essentially free of major contaminant fungi, particularly Olpidium sp. Contamination with Pythium and Phytophthora did not present a problem because their development time under our conditions ( $2-3 \mathrm{wk}$ ) was such that, even if present, they would not have been abundant at 8 days post-infection when root samples were generally collected. A suspension of distilled water: soil (5: $1(w / w))$ was prepared. After thoroughly homogenizing, $1 \mathrm{ml}$ of suspension was pipetted into glass test tubes $(1 \times 6 \mathrm{~cm})$. One pregerminated seed of sugar beet, cv Monosvalof, was placed in each tube so that the seed adhered to the side above the meniscus. After 5-9 days at $22^{\circ} \mathrm{C}$, the presence of fungus was checked microscopically and virus was detected by ELISA.
To obtain older infected plants, a sand culture of plants was established in propylene centrifuge tubes. A suspension of virus-carrying cytosori from infected beet roots was added to each plant. Twice a week, the plants were watered with a complete nutrient solution. Plants were harvested 2 or 5 wk after infection. Older roots with cystosori and younger roots in which zoosporangia were prevalent were embedded separately.

\section{Embedding}

Pieces of rootlets $(1.5 \mathrm{~mm}$ long) containing $P$ betae were fixed in $2.5 \%$ glutaraldehyde in $0.1 \mathrm{M}$ phosphate buffer $(\mathrm{pH} \mathrm{7.2)}$ for $2 \mathrm{~h}$ and postfixed in 1\% osmium tetroxide for $1 \mathrm{~h}$ at $4{ }^{\circ} \mathrm{C}$. After rinsing in distilled water, they were dehydrated in a graded ethanol series and penetrated with LR White resin or passed through propylenoxide and penetrated with a mixture of EponAraldite resins. The blocks were cured for $2 \mathrm{~d}$ at $60^{\circ} \mathrm{C}$ to polymerize the resin.

\section{Immunolabelling}

Ultrathin sections silver to gold in colour were cut with an LKB Ultrotome III and collected onto Pioloformcovered nickel grids.

The procedure for immunolabelling was set up using leaf sections of Chenopodium quinoa, a local lesion host of BNYVV, which is present in local lesions in greater quantity and is more easily detected than in roots of beet. The optimal procedure giving a good signal/background ratio in our hands was as follows: immunolabelling was done by placing the grids facedown on drops of solutions. As a first step, sections were treated with a saturated sodium metaperiodate solution for $30 \mathrm{~min}$ at room temperature to restore protein antigenicity of the osmium-treated tissue sections (Bendayan and Zollinger, 1983). This step was omitted for LR White embedded tissues.

Non-specific binding of antiserum was prevented by floating the grids on $1 \%$ bovine serum albumin in PBS (PBS-BSA) for $15 \mathrm{~min}$. One $\mathrm{ml}$ of anti-BNYVV antiserum raised in rabbit was absorbed with a healthy sugar beet preparation $(1 \mathrm{~g}$ tissue in $1 \mathrm{ml} 0.1 \mathrm{M}$ phosphate buffer) and clarified by low speed centrifugation (Langenberg and Van der Wal, 1986). This serum was then used diluted with PBS-BSA buffer 1:500 for Epon-Araldite-embedded tissues and 1:5000 for LR White-embedded tissues.

As controls, rabbit preimmune serum and antitobacco mosaic virus (anti-TMV) serum were used. After an incubation for $4 \mathrm{~h}$ at $37^{\circ} \mathrm{C}$, the grids were thoroughly rinsed on PBS-BSA drops. Then, a conjugate of protein A with colloidal gold (diameter $15 \mathrm{~nm}$, Biocell ref: EM GAR 15) diluted with PBS-BSA 1 : 10 for EponAraldite embedded tissues and 1:50 for LR White embedded tissues, was applied for $2 \mathrm{~h}$ at $37^{\circ} \mathrm{C}$. After another stringent wash with Millipore-filtered water, the 
sections were stained with uranyl acetate and lead citrate and examined in the electron microscope (Hitachi $\mathrm{HU}-11 \mathrm{C}-\mathrm{S}$ ) at $75 \mathrm{kV}$.

\section{RESULTS}

\section{Labelling specificity}

With the exception of a very low background, non-specific labelling of non-viruliferous Polymyxa betae was observed at any stage of its life cycle, either with the BNYVV antiserum or with the preimmune serum used as control.

Furthermore, using the anti-TMV serum, no specific reaction between viruliferous fungus and antiserum was seen and in particular the clusters of visible BNYVV particles present in the plant cytoplasm and the fungus were not labelled. Finally, the very characteristic appearance of BNYVV in infected cells (particles in angle-layered clusters; Putz and Vuittenez, 1980), makes it possible to recognize the virus under its colloidal gold labelling. The specificity of the labelling for BNYVV is thus acceptable. The amount of labelling observed for tissue embedded in Epon-Araldite was low compared to tissue embedded in LR White. This may be due to incomplete restoration of antigenicity during the sodium metaperiodate treatment using the former embedding medium.

\section{Life cycle of $P$ betae and presence of virus}

In most sections we could observe several stages of the fungus life cycle.

\section{Free zoospores}

Occasionally, in close proximity to roots free zoospores were observed containing virus in their vacuoles or vesicles (fig 1). We do not know if these are primary zoospores issued from cystosori in the soil or secondary zoospores because in such roots we have also observed labelled virus in zoospores of mature zoosporangia.

\section{Young plasmodia}

Young plasmodia of different dimensions were frequently present in the infected roots. Being usually very electron-opaque, they contained large amounts of fibrous material, which rendered it very difficult to identify virus if it was not

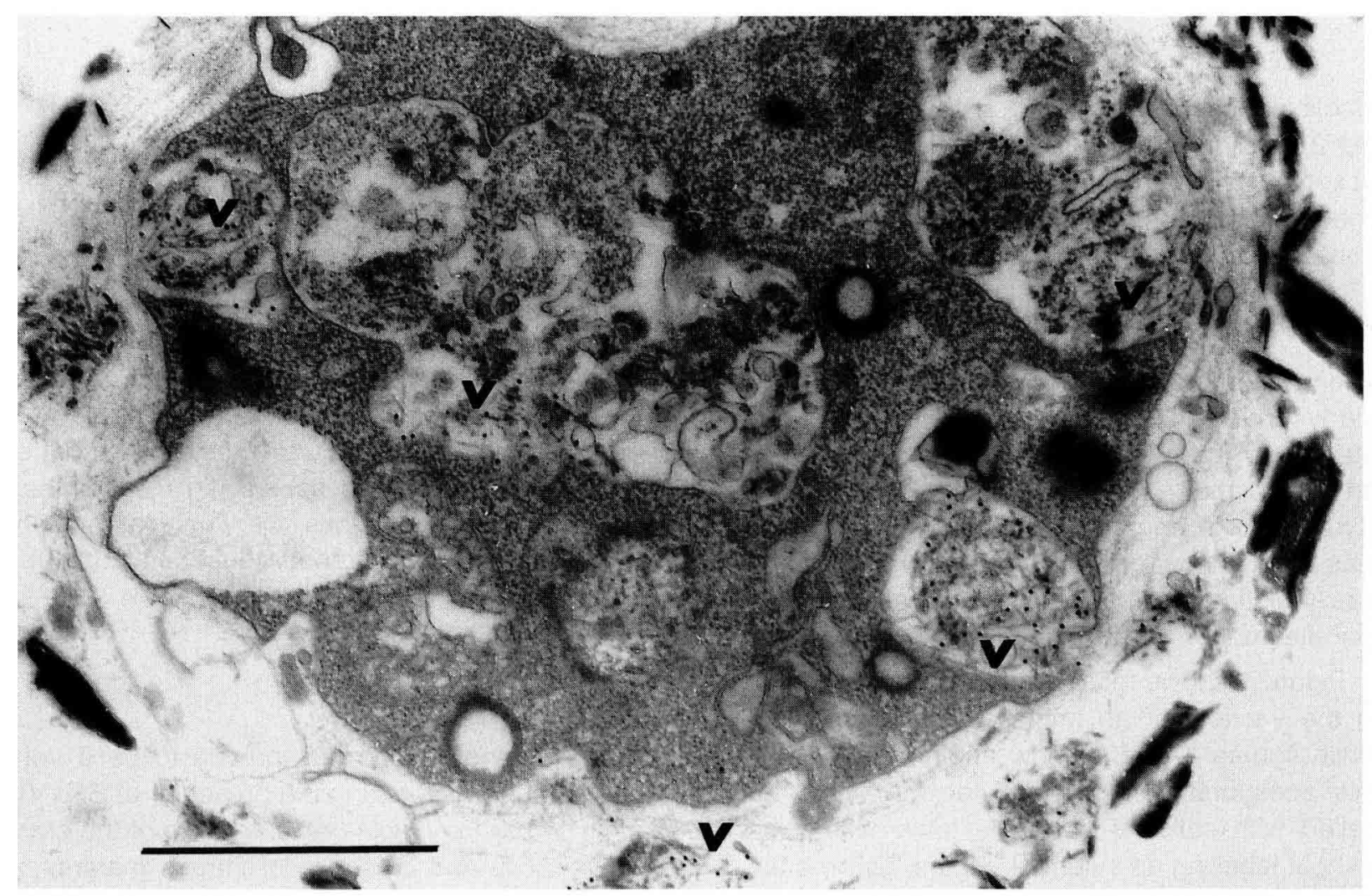

Fig 1. Free zoospore found in the proximity of a root hair. Several vacuoles and pinocytotic vesicles contain immunogold-labelled virus $(v)$. Labelled virus is likewise found outside the zoospore. Bar $=1 \mu \mathrm{m}$. 


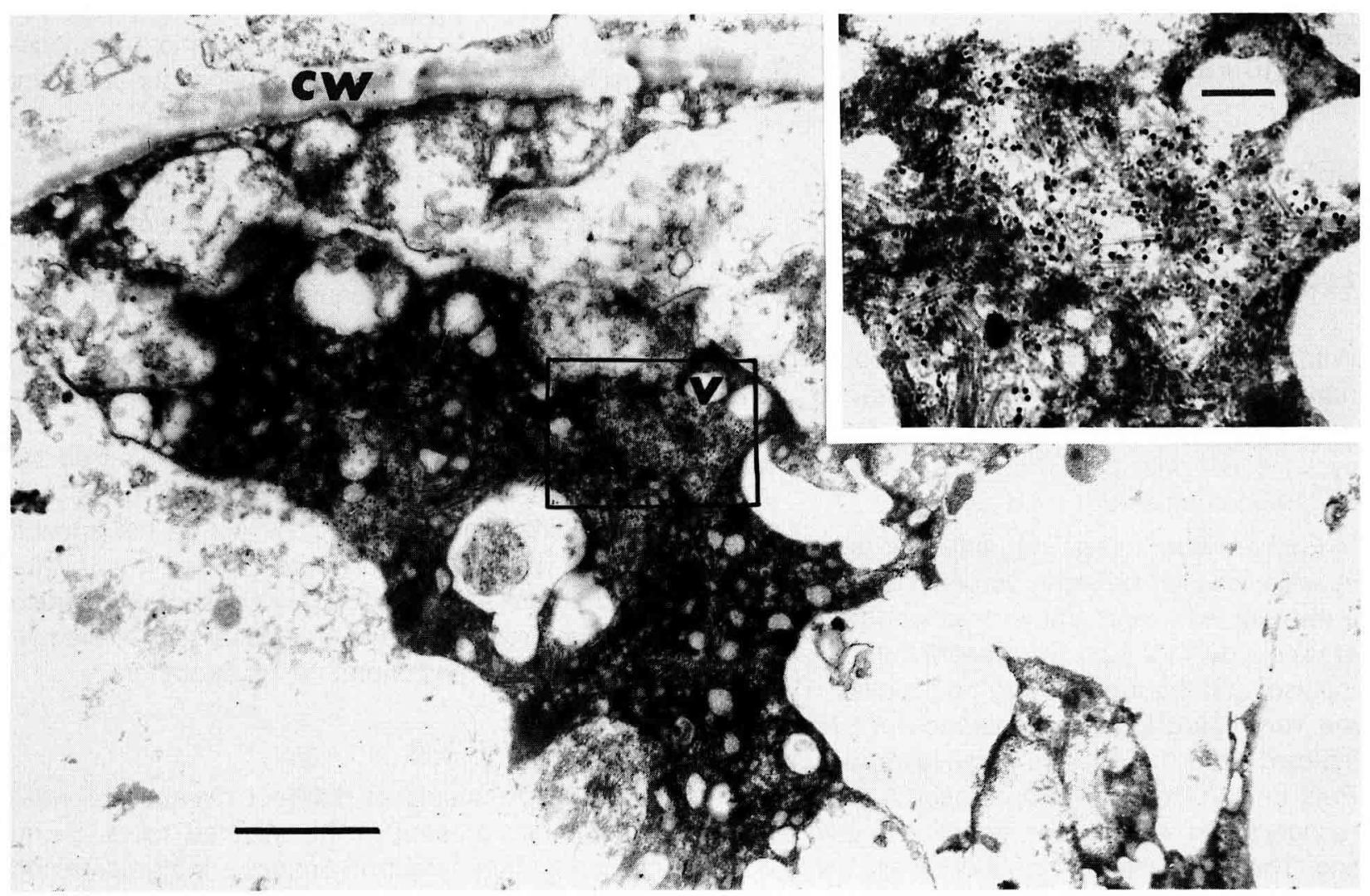

Fig 2. A young dense plasmodium with labelled virus particles in a less dense zone. Bar $=500 \mathrm{~nm}$. The insert shows detail of the virus-containing zone. $B a r=100 \mathrm{~nm}$.

labelled. Virus was often observed at this stage (fig 2) but it was not possible to determine from observation whether the plasmodium was destined to evolve into a zoosporangial or cytogenous structure.

\section{Zoosporangial plasmodia}

The immature zoosporangia were usually irregularly shaped. Osmophilic vesicles were numerous in the fungus and virus particles located in small clusters were observable. Cytoplasm of immature zoosporangium (fig 3) was electron-opaque but flagella were already easily distinguishable. Virus was present in this cytoplasm.

Figure 4 shows more clearly the labelled virus in the vacuole of an immature zoosporangium while figures 5 and 6 show another vacuole of this zoosporangium, the former with virus labelled with colloidal gold, the latter with virus without labelling as a control. Figure 7 shows the virus inside separated zoospores after cleavage of the zoosporangium.

\section{Cystogenous plasmodia}

We have found several putative cystogenous plasmodia with BNYVV inside. There may be a tendency to exclude the virus during the cleavage of resting spores inside the plasmodium. Alternatively, virus may be present but more difficult to detect in the interior of plasmodia. We could always observe virus near the internal cleavage sites, but it would not be possible with our observations to be sure whether it would remain inside the resting spores (fig 8) after their maturation. In other cases, the virus was present in an area that would probably degenerate (fig 9).

\section{DISCUSSION}

Gold immunolabelling has proven to be a very useful tool for searching the presence of BNYVV in its vector Polymyxa betae. In spite of the electron-opacity and presence of fibrous material in the fungus, virus was rapidly and clearly distinguished by association with its gold label. All the 


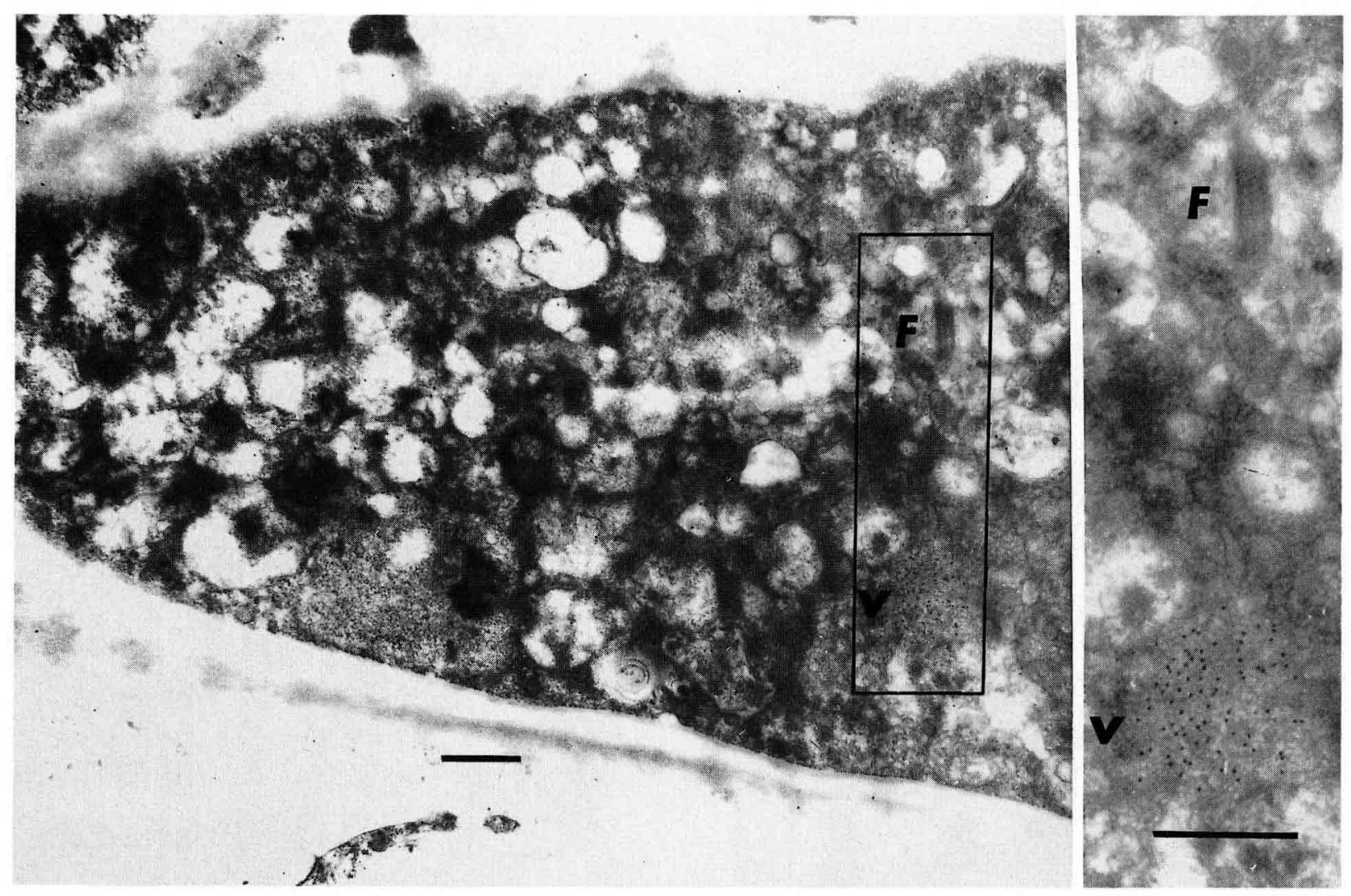

Fig 3. Longitudinal section in a root hair completely filled with a zoosporangial plasmodium. A gold-labelled region (v) and a flagellum $(F)$ are visible. $B a r=500 \mathrm{~nm}$.

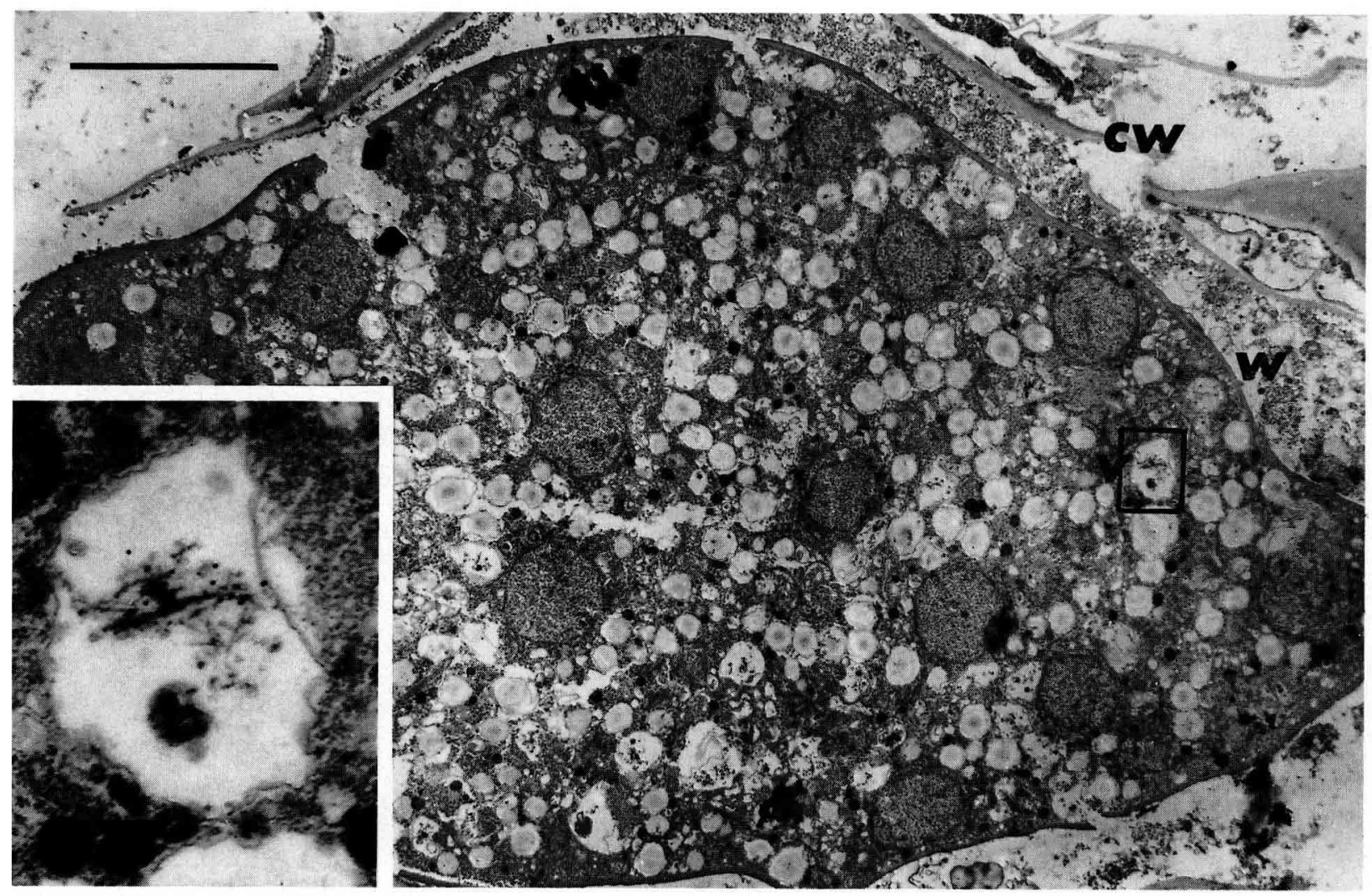

Fig 4. Immature zoosporange containing labelled virus within numerous vacuoles $(w=$ fungus wall: $\mathrm{cw}=\mathrm{cell}$ wall). Insert shows one such vacuole. Bar $=200 \mathrm{~nm}$. 

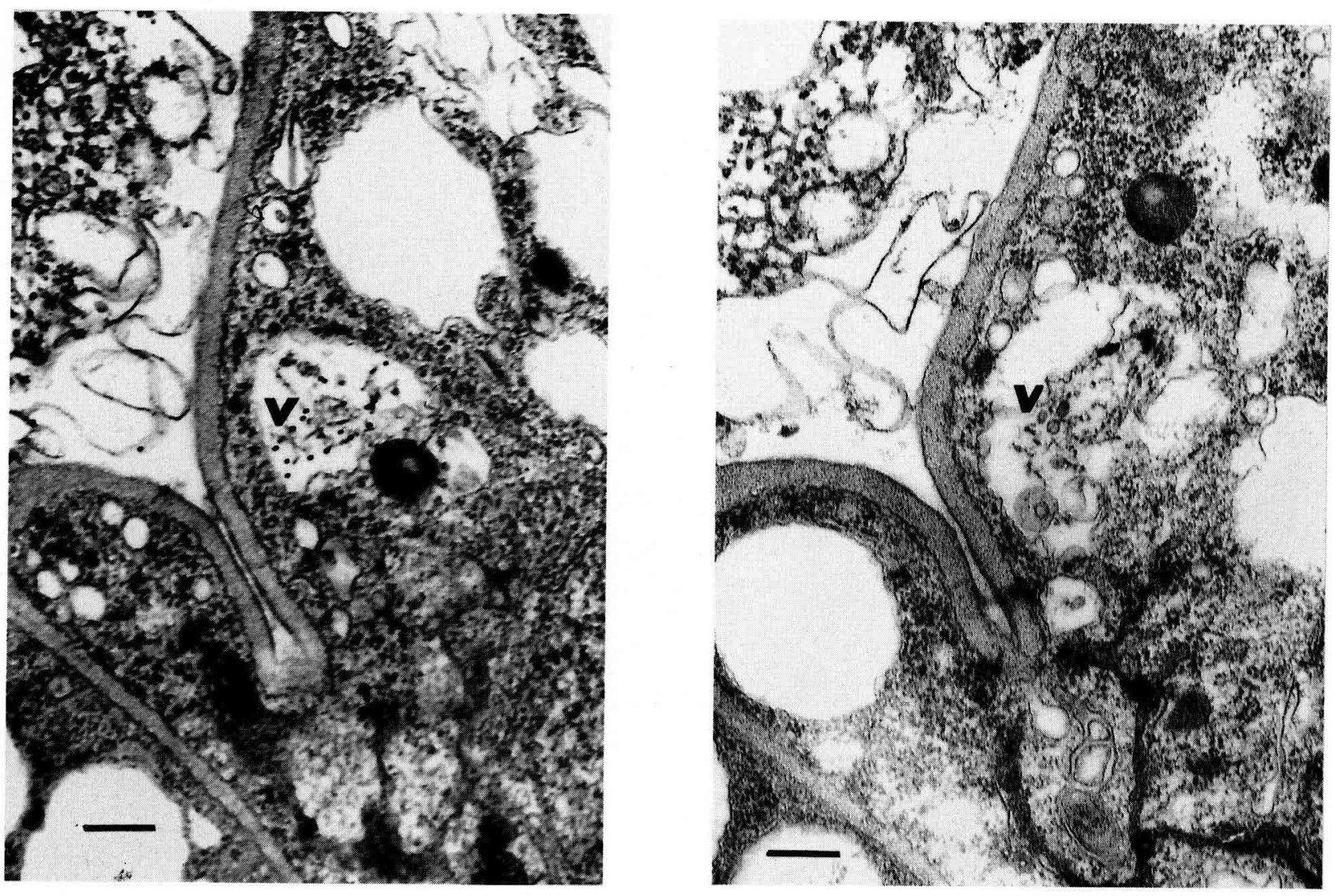

Figs 5-6. Zoosporangial plasmodium. 5. Gold-labelled virus in the structure. 6. A neighbouring thin section but without gold-labelling in which non-labelled virus can be distinguished. $B a r=200 \mathrm{~nm}$.

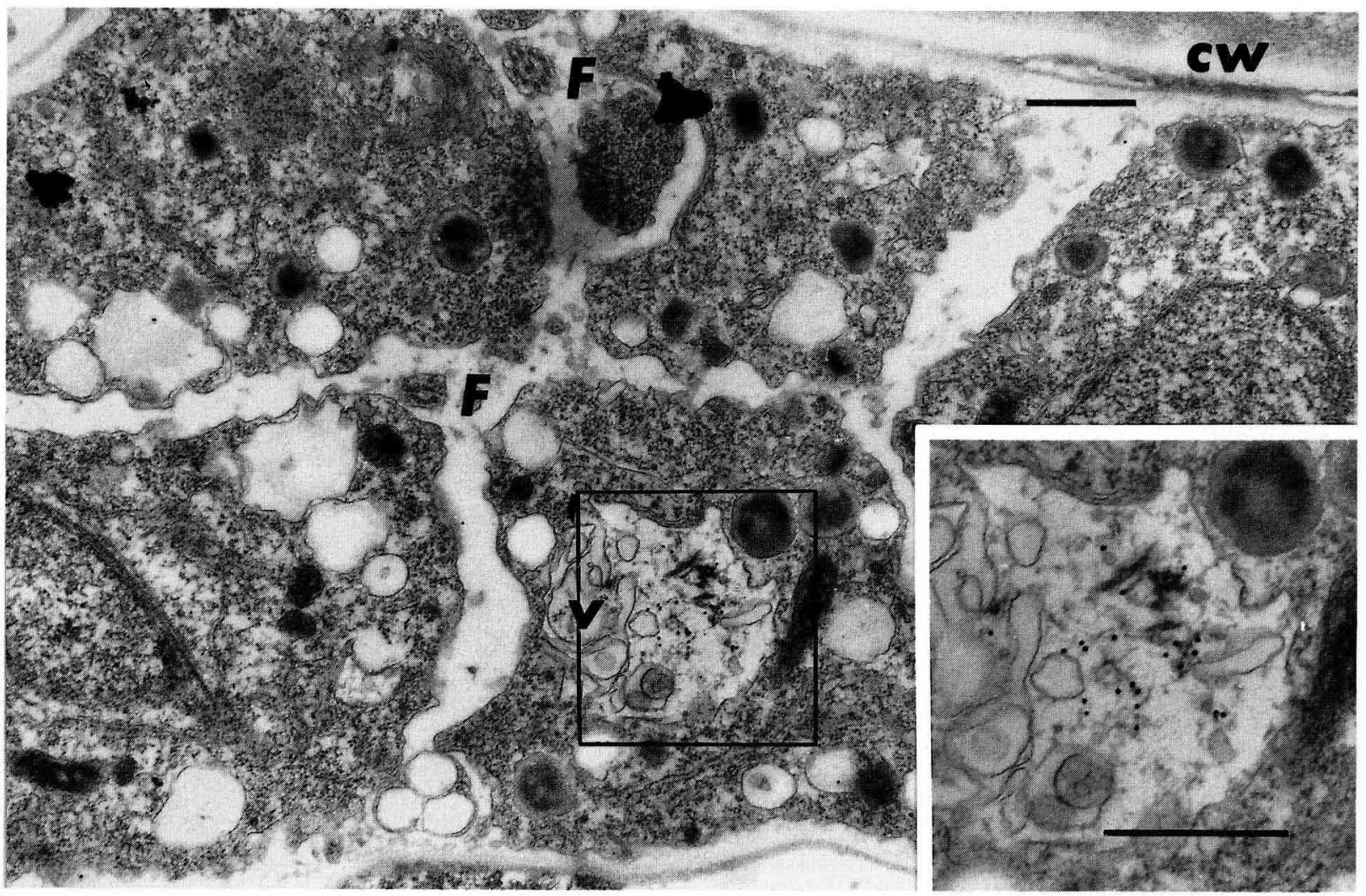

Fig 7. A zoosporangium containing individual zoospores. Gold labelling in the interior of a vacuole of one zoospore (insert) reveals the presence of virus. Bar $=500 \mathrm{~nm}$. 


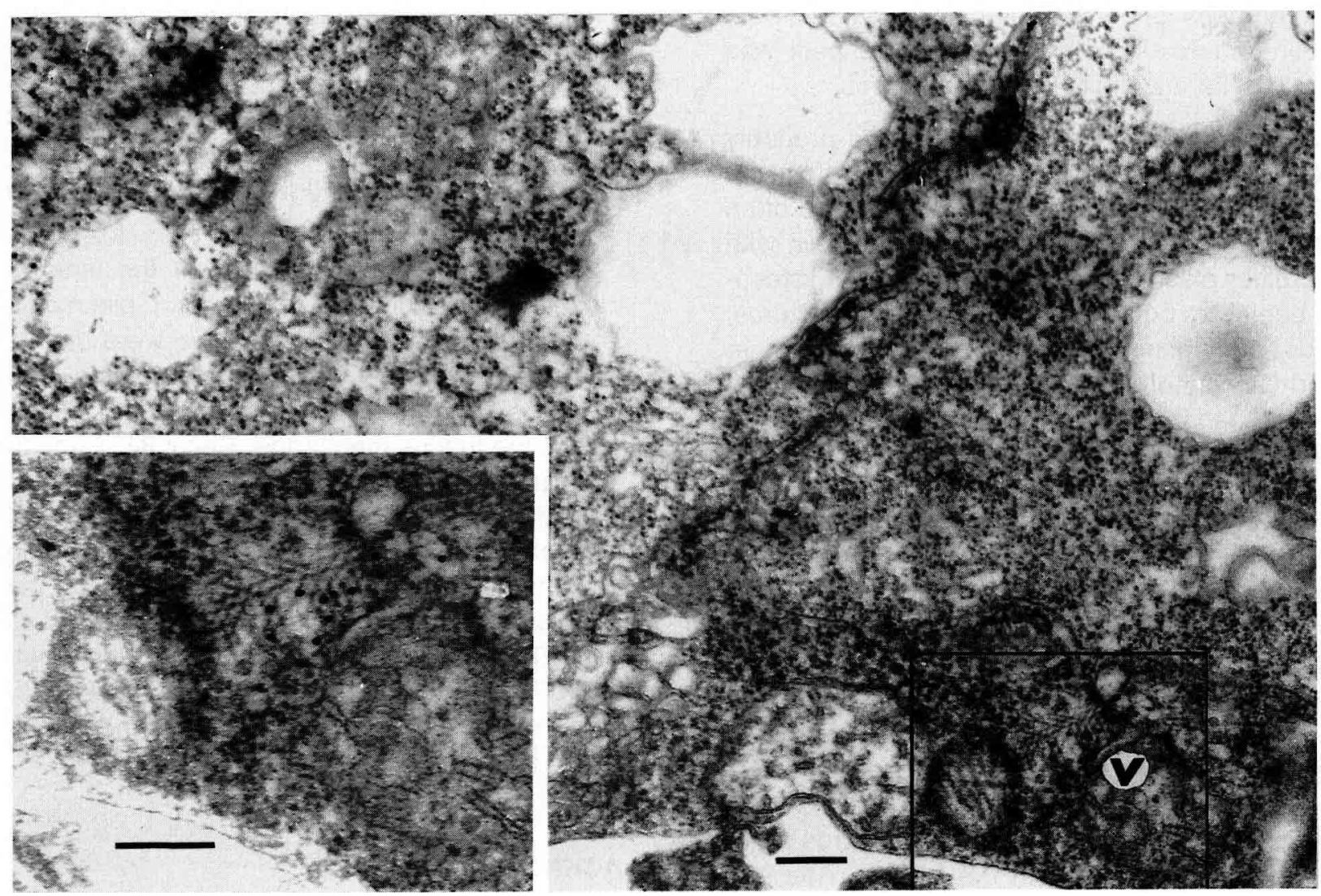

Fig 8. Cystogenic plasmodium with gold-labelled virus aggregated in chevrons. Bar $=200 \mathrm{~nm}$.
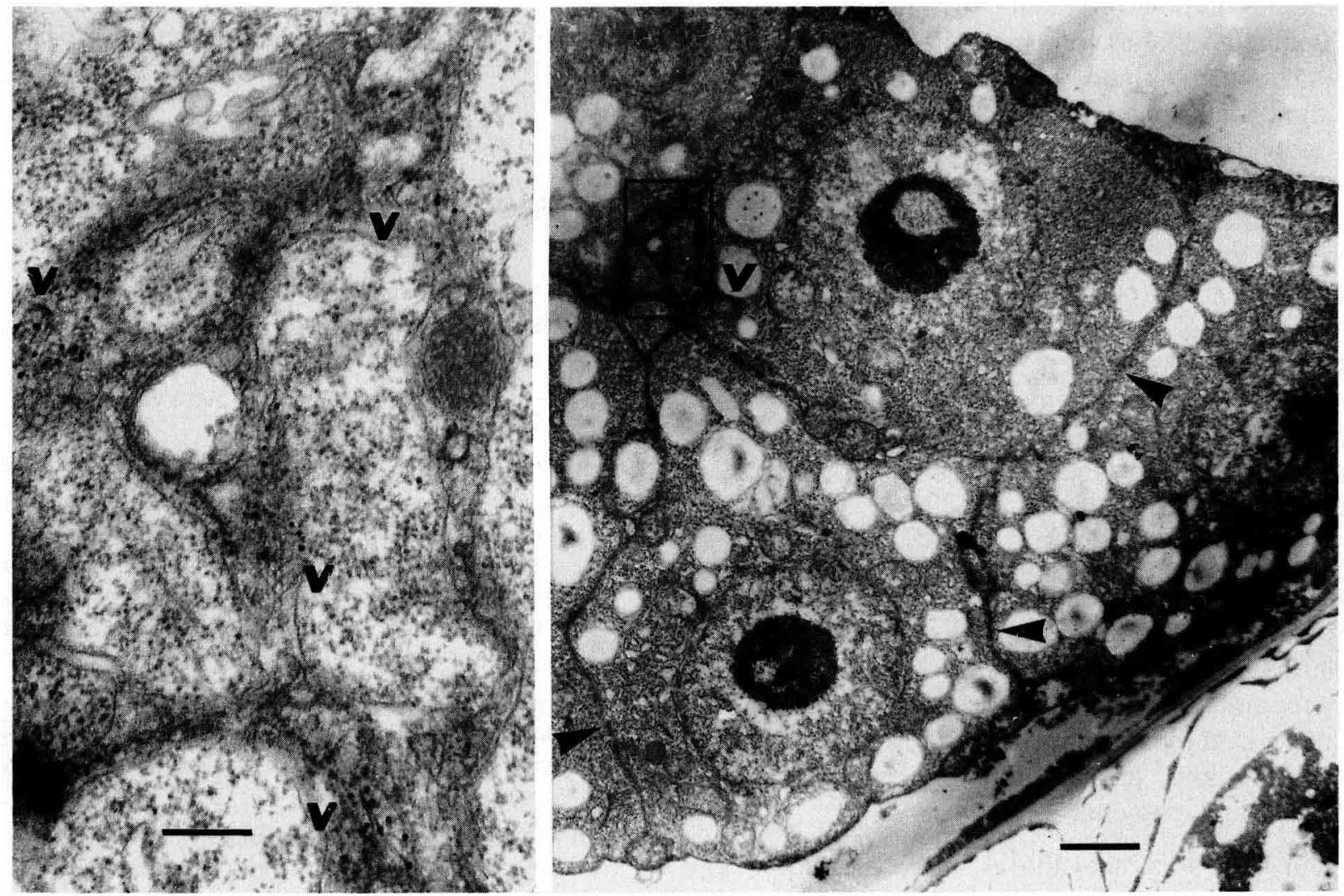

Fig 9. Cystogenic plasmodium undergoing cleavage (arrows). Bar $=1 \mu \mathrm{m}$. In the insert several aggregates of gold-labelled virus can be seen. $B a r=200 \mathrm{~nm}$ 
micrographs presented here were issued from Epon-Araldite inclusions in which contrast was much better than in LR White inclusions.

The amount of virus in the fungus probably depends on the amount of virus in the host cell at the time of infection by the fungus. We often observed large amounts of virus in contact with the older plasmodia, zoosporangia and cystoso$\mathrm{ri}$, but it was not present inside these structures, thus confirming observations of Langenberg and Giunchedi (1982). In the roots of 7-day-old plants the virus was found in the young plasmodia (in large amounts), in zoosporangial and cystogenous plasmodia and in immature zoospores (in small amounts) but not in mature zoospores. In young plasmodia we observed a number of pinocytotic vesicles that are probably responsible for liberating virus from or acquiring virus by plasmodium. The virus was often present in young plasmodia in certain areas which could correspond to vesicles generated by picnocytosis. Thus we suppose that, after some time, the acquisition of virus by plasmodium is impossible. If we assume that virus probably does not multiply in the fungus (Abe and Tamada, 1986), the very low amounts of virus injected into the cell by a zoospore would escape our methods of detection. We did not count the number of fungal structures observed, but estimate that in some cases at least $50 \%$ of plasmodia contained virus. Nevertheless, it is evident that after differentiation into zoospores or resting spores only some of them will carry the virus. The fact that we have failed to find virus in mature resting spores can probably be attributed to the low number of well-embedded cystosori of appropriate age observed. Howev$e r$, in spite of the apparent exclusion of virus from plasmodia during cleavage of resting spores, in view of the amount of virus observed in the free zoospores, it appears likely that the amount of virus in resting spores should be sufficient for being detected.

We did not try to pellet free zoospores of Polymyxa betae as did Jianping et al (1991), with zoospores of Polymyxa graminis, because pure cultures of Polymyxa betae were not available. In preparations of free zoospores from partially purified cultures, contaminants (chytridial fungi, amoebae and algae) were always present (Wiedemann, personal communication).

Our data show that the in situ localization of labelled BNYVV particles is possible at all stages of the Polymyxa betae life cycle except for the electron-dense mature resting spores. It is noteworthy that the virus appeared mainly in vacuoles of the zoosporangia, but not in those of the cystogenous plasmodia. The viral clusters found mainly at the external side of cystogenous plasmodia, were smaller and less numerous than in the zoosporangial plasmodia.

Our results clearly indicate that the virus is carried inside zoospores by young plasmodia and by zoosporangia; however, we were unable to explain whether the fungus acquires and transmits BNYVV by pinocytosis or by passage across the fungus membrane. Recently, Tamada and Kusume (1991) indicated that the 75-K readthrough protein encoded by RNA 2 is essential for transmission of BNYVV by $P$ betae. The transmission efficiency is also enhanced by the $31-\mathrm{K}$ protein encoded by RNA 4 (Lemaire et al, 1988; Tamada and Abe, 1989). It will be interesting to localize these proteins by the same goldlabelling technique in order to determine their role in the transmission mechanism.

\section{ACKNOWLEDGMENTS}

This work was mostly carried out during a 1-year postdoctoral stay at INRA Colmar by P Rysanek; we thank the Centre International des Étudiants et Stagiaires (CIES Paris) for financial support during this period and Ken Richards (IBMP Strasbourg) for precious help with the manuscript.

\section{REFERENCES}

Abe H, Tamada T (1986) Association of beet necrotic yellow vein virus with isolate of Polymyxa betae Keskin. Ann Phytopathol Soc Jpn 52, 235-247

Adams MJ (1991) Transmission of plant virus by fungi. Ann Appl Biol 118, 479-492

Allaham AW, Stocky G (1983) Contribution à l'étude de la contagion naturelle de la rhizomanie de la betterave : acquisition, transmission et conservation du virus des nervures jaunes et nécrotiques de la betterave par le champignon Polymyxa betae Keskin (Plasmodiophoromycetae). Thèse de doctorat d'Université Paris VI, $158 \mathrm{p}$

Bendayan M, Zollinger M (1983) Uitrastructural localization of antigenic sites on osmium-fixed tissues applying the protein $\mathrm{A}$-gold technique. $J$ Histochem Cytochem 31, 101-109

Brunt AA, Richards KE (1989) Biology and molecular biology of furoviruses. Adv Virus Res 36, 1-32

Canova A (1966) Si studia la rizomania della bietola. Inf Fitopatol 10, 235-239 
D'ambra V, Mutto S (1975) Ultrastruttura di Polymyxa betae Keskin Plasmodo, sporangio e cistosoro. Riv Patol Veg $11,115-124$

Fujisawa I, Sugimoto T (1977) Transmission of beet necrotic yellow vein virus by Polymyxa betae. Ann Phytopathol Soc Jpn 43, 583-586

Giunchedi L, Langenberg WG (1982) Beet necrotic yellow vein virus by Polymyxa betae Keskin zoospores. Phytopathol Mediterr 21, 5-7

Jianping C, Swaby AG, Adams MJ, Yili R (1991) Barley mild mosaic virus inside its fungal vector, Polymyxa graminis. Ann Appl Biol 118, 615-621

Keskin B (1964) Polymyxa betae n sp, ein Parasit in den Wurzeln von Beta vulgaris Tournefort, besonders während der Jugendentwicklung der Zuckerrübe. Arch Mikrobiol 49, 348-374

Keskin B, Fuchs WB (1969) Der Infektionsvorgang bei Polymyxa betae. Arch Mikrobiol 68, 228-226

Langenberg WG, Giunchedi L (1982) Ultrastructure of fungal plant virus vectors Polymyxa graminis in soilborne wheat mosaic virus-irfected wheat and $P$ betae in beet necrotic yellow vein virus-infected sugar beet. Phytopathology 72, 1152-1158

Langenberg WG, Van der Wal D (1986) Identification of barley yellow mosaic virus by immunoelectron microscopy in barley but not in Polymyxa graminis or Lagena radicicola. Neth J Plant Pathol 92, 133-136

Lemaire $O$, Merdinoglu D, Valentin P, Putz C, ZieglerGraff V, Guilley H, Jonard G, Richards K (1988) Effect of beet necrotic yellow vein virus RNA composition on transmission by Polymyxa betae. Virology $162,232-235$

Putz C, Vuittenez A (1980) The intracellular location of beet necrotic yellow vein virus. J Gen Virol 50,201 204

Stocky G, Vuittenez A, Putz C (1977) Observation "in situ" of rod-like particles, probably the rhizomania vi- rus itself (beet necrotic yellow vein) in various Chenopodiaceae experimentally inoculated by the virus and in the fungus Polymyxa betae Keskin infecting roots of these host-plants. Ann Phytopathol 9, 536537

Tamada T (1975) Beet Necrotic Yellow Vein Virus. CMI/AAB. Descriptions of plant viruses, $n^{\circ} 144,5 p$

Tamada T, Abe $H$ (1989) Evidence that beet necrotic yellow vein virus RNA 4 is essential for efficient transmission by the fungus Polymyxa betae. $J$ Gen Virol 70, 3391-3398

Tamada T, Baba T (1973) Beet necrotic yeilow vein virus from rhizomania-affected sugar beet in Japan. Ann Phytopathol Soc Jpn 39, 325-332

Tamada T, Kusume T (1991) Evidence that the 75-K readthrough protein of beet necrotic yellow vein virus RNA 2 is essential for transmission by the fungus Polymyxa betae. J Gen Virol 72, 14971504

Tamada T, Abe H, Baba T (1975) Beet necrotic yellow vein virus and its relation to the fungus Polymyxa betae. In: Infection and Antimicrobial Agents. Vol 3 (Hasegawa T, ed) Proc 1st Intersect Congr IAMS Tokyo 1974. Science Council of Japan, 313320

Vuittenez A, Stocky G (1979) Similar aspect of rodlike particles observed in plants infected by beet necrotic yellow vein virus and in the associated fungus Polymyxa betae Keskin, Myxomycetae vector of the virus. Ann Phytopathol 11, 135-136

Vuittenez A, Stocky G, Allaham AW (1984) Presentation of photomicrographs showing association of beet necrotic yellow vein virus (BNYVV) with its fungus vector Polymyxa betae $\mathrm{K}$ in root cells of plants inoculated from beet Beta vulgaris Tourn affected with rhizomania. In: Proc Ist Intern Conf Sugar Beet Rhizomania Virologists. IIRB/INRA Colmar 7-8/6/1984, 53-69 